\title{
ULTRASONIC INSPECTION FOR LACK OF PENETRATION AND POROSITY IN A TUNGSTEN INERT GAS WELD WITH A STEP GEOMETRY
}

M. W. Moyer

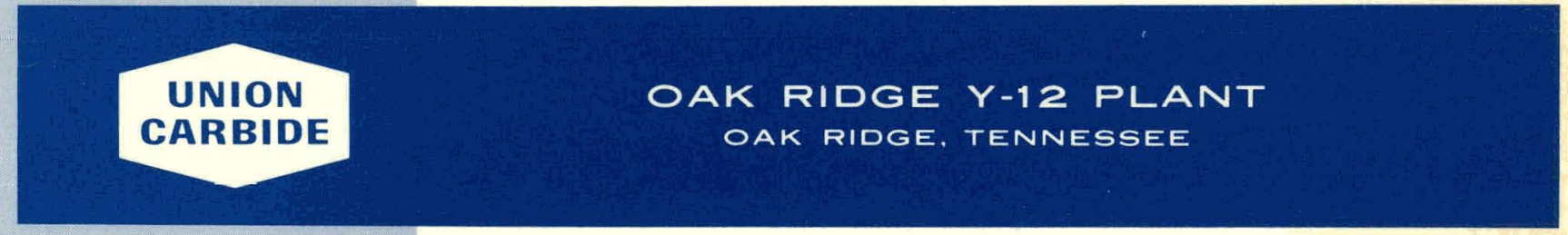

prepared for the U.S. ENERGY RESEARCH AND DEVELOPMENT ADMINISTRATION under U.S. GOVERNMENT Contract W-7405 eng 26 


\section{DISCLAIMER}

This report was prepared as an account of work sponsored by an agency of the United States Government. Neither the United States Government nor any agency Thereof, nor any of their employees, makes any warranty, express or implied, or assumes any legal liability or responsibility for the accuracy, completeness, or usefulness of any information, apparatus, product, or process disclosed, or represents that its use would not infringe privately owned rights. Reference herein to any specific commercial product, process, or service by trade name, trademark, manufacturer, or otherwise does not necessarily constitute or imply its endorsement, recommendation, or favoring by the United States Government or any agency thereof. The views and opinions of authors expressed herein do not necessarily state or reflect those of the United States Government or any agency thereof. 


\section{DISCLAIMER}

Portions of this document may be illegible in electronic image products. Images are produced from the best available original document. 
Reference to a company or product name does not imply approval or recommendation of the product by Union Carbide Corporation or the U.S. Energy Research and Development Administration to the exclusion of others that may meet specifications.

Printed in the United States of America. Available from Natlonal Techrnical Infurmatiun Service

U.S. Department of Commerce

5285 Port Royal Road, Springfield, Virginia 22161

Price: Printed Copy $\$ 4.00$; Microfiche $\$ 2.25$

This report was prepared as an account of work sponsored by the United States Government. Neither the United States nor the Energy Research and Development Administration, nor any of their employees, nor any of their contractors, subcontractors, or their employees, makes any warranty, express or implied, or assumes any legal liability or responsibility for the accuracy, completeness or usefulness of any information, apparatus, product or process disclosed, or represents that its use would not infringe privately owned rights. 


\title{
ULTRASONIC INSPECTION FOR LACK OF PENETRATION AND POROSITY IN A TUNGSTEN INERT GAS WELD WITH A STEP GEOMETRY
}

\author{
M. W. Moyer \\ Laboratory Development Department \\ Y-12 Development Division
}

This report was prepared as an account of work sponsored by the United States Government. Neither the United States nor the United States Energy Research and Development Administration, nọ any of their employees, nor any of their contractors, subcontractors, or thcir cmployecs, makes any warranty, express or implied, or assumes any legal liability or responsibility for the accuracy, completeness lability or responsibility for the accuracy, completeness
or usefulness of any information, apparatus, product or process disclosed, or represents that its use would not infringe privately owned rights.

Oak Ridge $Y-12$ Plant

P. O. Box Y, Oak Ridge, Tennessee 37830

Prepared for the US Energy Research

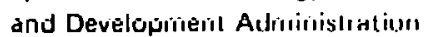
Under US Government Contract W-7405-eng-26 


\section{ABSTRACT}

Ultrasonic techniques were used to certify the penetration and porosity in three structural welds in Type AM 363 stainless steel. A normal beam technique detects a lack of penetration after the root-fusion weld pass. Shear-wave, angled-beam immersion techniques are used after the filler pass to detect any lack of penetration that is as large as $0.5 \mathrm{~mm}$ and porosity ranging in size from 0.5 to $1.3 \mathrm{~mm}$. 
CONTENTS

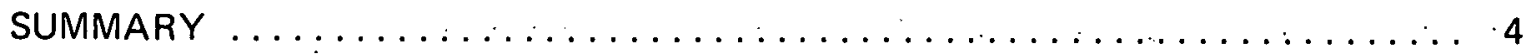

INTRODUCTION $\ldots \ldots \ldots \ldots \ldots \ldots \ldots \ldots \ldots \ldots \ldots \ldots \ldots \ldots \ldots \ldots \ldots$

DESIGN AND APPLICATION OF THE ULTRASONIC TESTING TECHNIQUES . . . 6

Weld Geometry $\ldots \ldots \ldots \ldots \ldots \ldots \ldots \ldots \ldots \ldots \ldots \ldots \ldots \ldots \ldots \ldots \ldots \ldots$

Detection of Lack of Penetration $\ldots \ldots \ldots \ldots \ldots \ldots \ldots \ldots \ldots \ldots \ldots \ldots \ldots \ldots$

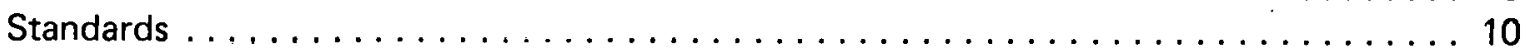

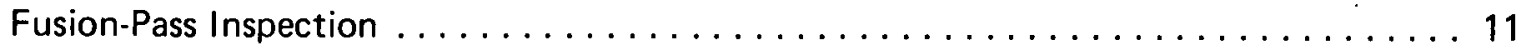

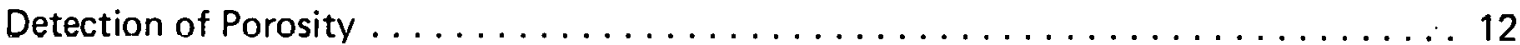

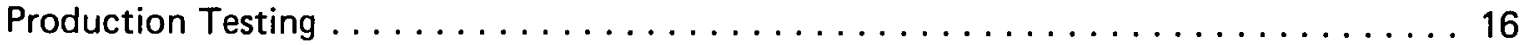

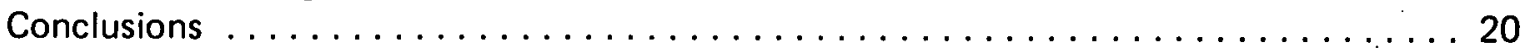

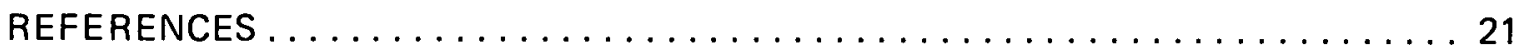

ACKNOWLEDGEMENTS $\ldots \ldots \ldots \ldots \ldots \ldots \ldots \ldots \ldots \ldots \ldots \ldots \ldots \ldots$ 


\section{SUMMARY}

Certification of a tungsten inert gas (TIG) weld with a deep chamfer step geometry has been accomplished by ultrasonic inspection techniques. The weld is fabricated in two steps: an initial root-fusion pass followed by a cold-wire filler pass. Lack of penetration and porosity are identified by ultrasonic inspection. A normal-beam technique detects lack of penetration after the root-fusion weld pass. Shear-wave, angled-beam immersion techniques are used after the filler pass to detect any lack of penetration that is as large as $0.5 \mathrm{~mm}$ and porosity ranging in size from 0.5 to $1.3 \mathrm{~mm}$. Photomicrographs of typical porosity and lack of penetration were taken to demonstrate the correlation between nondestructive ultrasonic inspection and weld quality. 


\section{INTRODUCTION}

There are numerous situations where welds are required to assemble the various components of a system. When uniform penetration or minimal distortion and heating of the rear surface is required, a step-weld geometry is commonly used. For welds in critical structures, nondestructive techniques are required to certify that the weld is sound; ie, no flaws exist that might be initiation sites for crack propagation.

This report describes the effort that was made at the Oak Ridge Y-12 Plant $(a)$ to develop the techniques to inspect and certify three structural tungsten inert gas (TIG) welds in Type AM 363 stainless steel. The joint configuration is a deep chamfer step geometry requiring two weld passes: an initial root-fusion pass followed by a cold-wire filler pass. Design requirements dictate that the weld penetrate or wipe out the step and that porosity be kept to a minimum. Ultrasonic techniques are most applicable to detect lack of complete fusion and locate porosity in the welds. Radiography has great difficulty in locating. closed flaws such as cold shuts, cracks, and lack of fusion. In addition, radiography cannot resolve small porosity in the welds.

Three steps were taken to develop the tests to inspect these welds: First, techniques were proposed to detect the undesirable conditions in the weld. (Inspection parameters such as transducer frequency and interference effects were considered.) Next, test samples were inspected and standards designed to simulate expected flaws. These techniques were used to determine a correlation between flaw response and standard response. Finally, the tests were proven on actual welds in the production environment. Design of the standards and experiments required to prove the ultrasonic technique should serve as a guide on which to base the inspection of future welds having a step-joint design.

(a) Operated by the Union Carbide Corporation's Nuclear Division for the US Energy Research and Develupment Administration. 


\section{DESIGN AND APPLICATION OF THE ULTRASONIC TESTING TECHNIQUES}

\section{WELD GEOMETRY}

The three welds of interest were fabricated in Type AM 363 stainless steel. Although all three welds were of similar geomtry, there were slight differences. One weld was fabricated with the weld plane (plane of joint intersection) normal to the weld surface; the second weld was used to weld a plate to a thicker section. In the third weld, the weld plane was inclined at 13 degrees from the normal to the weld surface. The joint geometries of the three welds are detailed in Figure 1.

The weld was fabricated in two steps: The first weld pass fused the root of the joint. Lack of complete fusion and flaws such as porosity, cracks, and cold shuts can occur In the fusiuı pass. It would be desirable to detect these conditions after the fusion pass, since repair would be easier, but the geometry of the weld at this point makes an interim inspection difficult. However, a technique to detect lack of fusion is described later in this report. A cold-wire filler pass follows the fusion pass. Incidentally, it is important that the filler wire be clean since contamination can cause porosity.

\section{DETECTION OF LACK OF PENETRATION}

To inspect the root of the completed weld for flaws and lack of fusion, a shear-wave angled-beam inspection was proposed. In ultrasonic technique development, Elox slots are usually used to represent a weld with incomplete penetration. Figure 2 depicts the ultrasonic energy being focused on and reflected from an Elox slot. It is assumed that the ultrasonic energy would be reflected in a similar, but not necessarily identical, fashion from a portion of weld which is not fused. The transducer emlts a pulse of lunigitudinal acoustic energy which is coupled to the weld by a water path. This pulse is refracted at the water/steel interface, the mode converted to shear energy, and focused at the corner formed by the slot and the rear surface of the material. A portion of the energy is specularly reflected twice by the corner and then returned along the transmitted path to the transducer. The amplitude of the reflected energy is dependent upon the height of the slot.

A smooth, monotonical increase of the reflected energy with increasing slot height is what is desired. Double-valued response curves are obtained when the dimensions of the corner or slot approach the wave length of sound. Frielinghaus, et al, $(1)$ indicate that, when groove dimensions are less than approximately two wave lengths, the echo has a rather complex structure, heing composed of several interfering waves (see Figure 3). The incident wave is specularly reflected from the two adjacent surfaces, as described in the preceding paragraph. Signal inversion occurs at each reflection so that Wave 1 is in phase with the incident wave. In addition, the edges of the slot are sources of scattered waves (Waves 2 and 3 in Figure 3) which propagate as cylindrical shear waves with the scattering edge as the cylinder axis. These signals are inverted upon scattering. Sume of the scattered energy from the top of the slot is reflected from the step, producing Wave 4 . In addition, mode conversion of the incident shear wave at the edges of the slot can generate surface waves (for. instance, Waves $S_{1}$ and $S_{2}$ ) which will partially change: their mode at the next edge and are reconverted into cylindrical shear waves (Waves 5 and 6 , Figure 3 ). 
The scattered energy from the top of the slot (Wave 2) can interfere with the specularly reflected energy (Wave 1), the scattered energy from the bottom of the slot (Wave 3), the reflected energy (Wave 4), or the energy from the mode-converted surface waves (Waves 5 and 6). It should be noted that, from geometrical considerations, Waves 1, 3, and 4 are coincident in time, as are Waves 5 and 6 . Thus, there are three interfering signal paths caused by the relative delay between signals. At a given frequency; the slot height for which interference may occur can be calculated if the wave length is known. The wave length, $\lambda$, is given by:

$$
\lambda=V s / f
$$

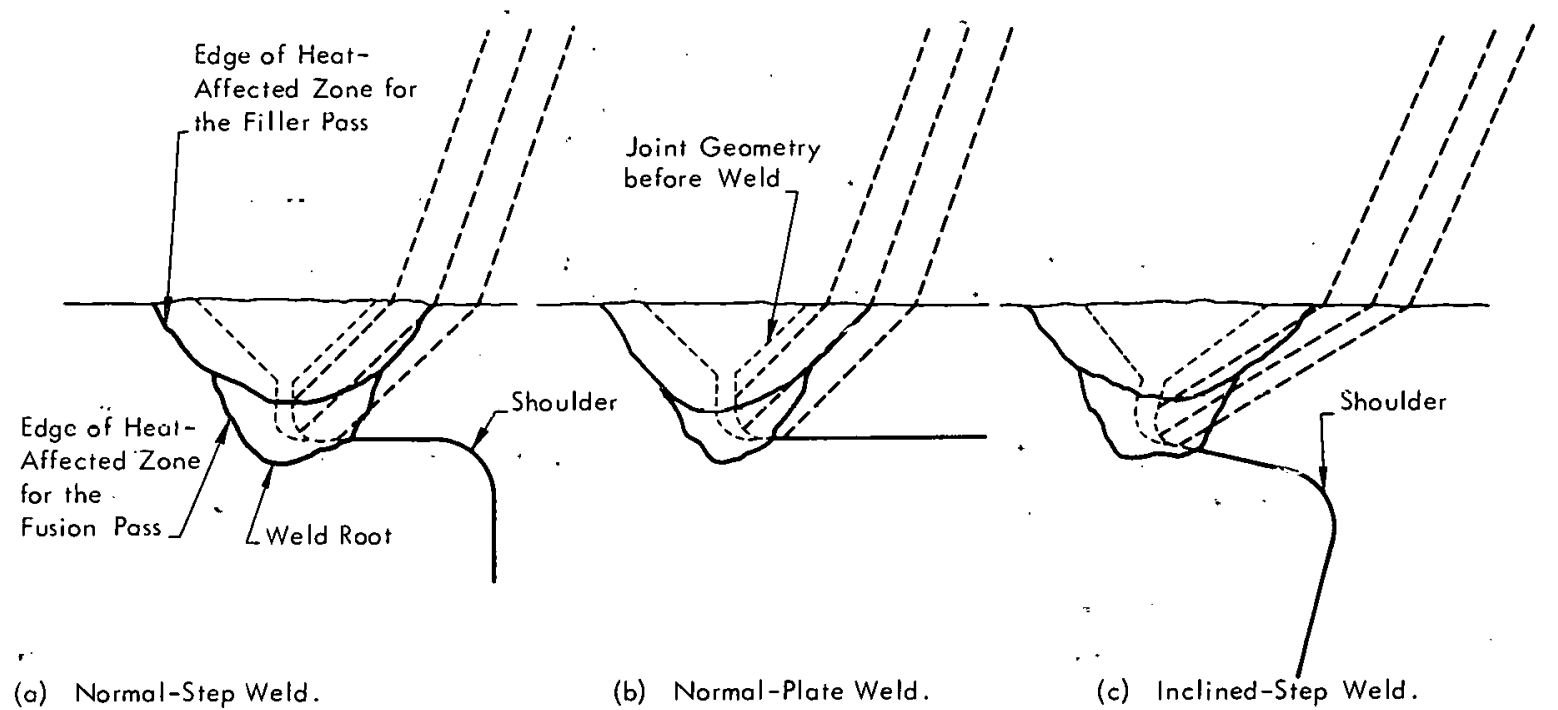

(a) Normal-Step Weld.

(b) Normal-Plate Weld.

(c) Inclined-Step Weld.

Figure 1. WELD GEOMETRY.

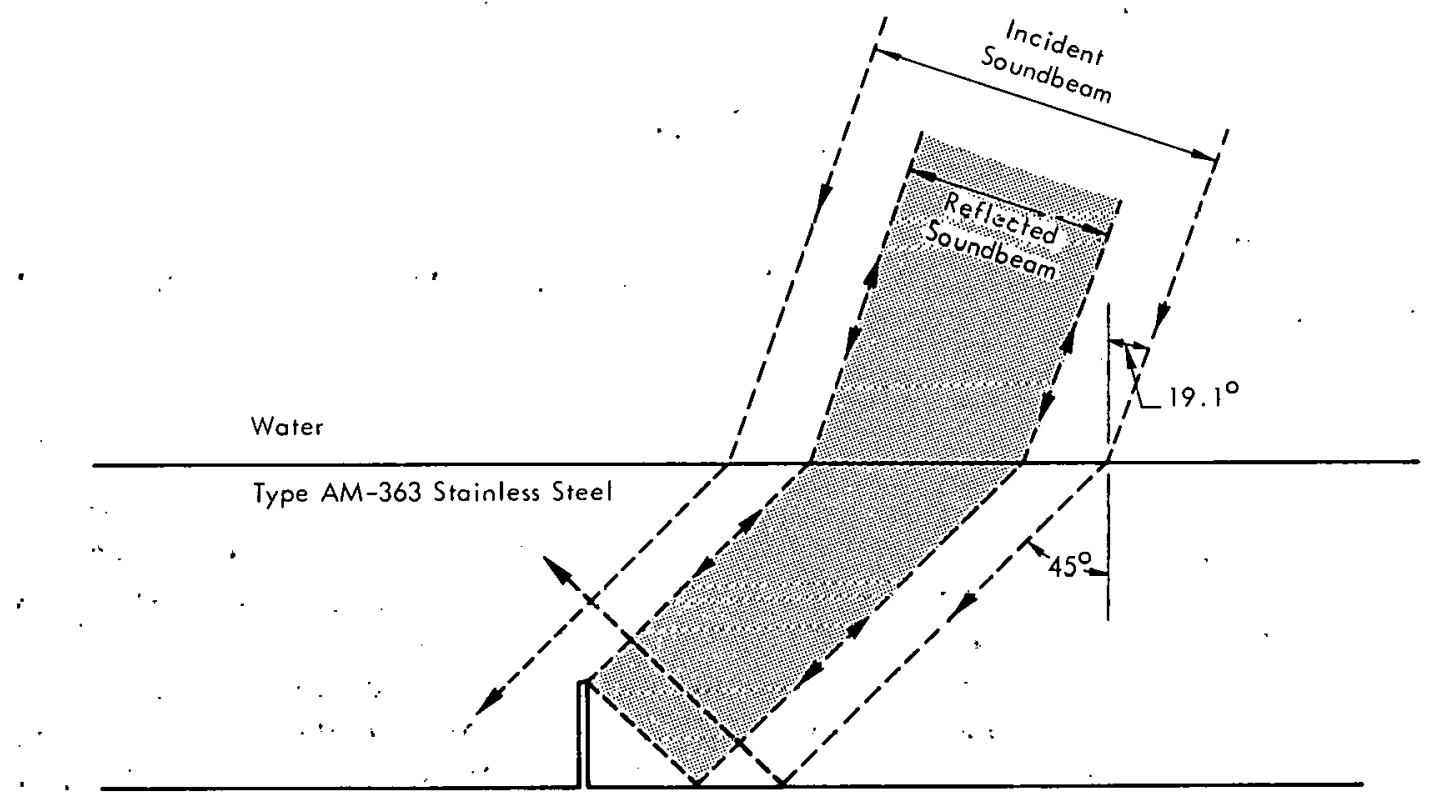

Figure 2. GEOMETRICAL MODEL FOR THE REFLECTION OF ULTRASOUND FROM AN ELOX SLOT. REPRESENTING LACK OF PENETRATION. 


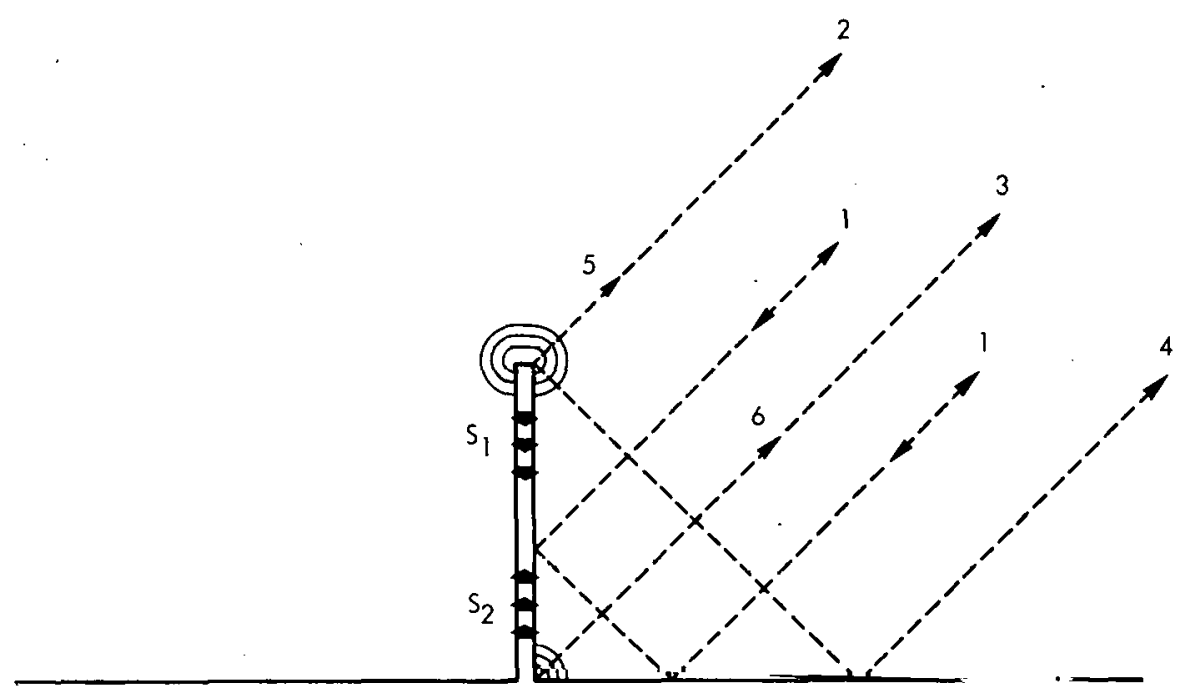

Figure 3. COMPLEX STRUCTURE OF A SOUND BEAM REFLECTED FROM AN ELOX SLOT, SHOWING THE VARIOUS INTERFERING WAVES FORMED.

where $f$ represents the frequency and $V s$ the shear velocity. Between the scattered energy from the top of the slot (Wave 2) and the specularly reflected energy (Wave 1), destructive interference occurs when the path difference is une wave length. The calculated slot height, $h$, for interference is given by:

$$
h_{21}=\frac{V s}{1.414 f}
$$

Between the scattered energy from the top of the slot (Wave 2) and the mode-converted energy (Waves 5 and 6 ), constructive interference can occur at a slot height given by:

$$
h_{25}=\frac{V r V s}{f(V s+0.707 V r)}
$$

where $\mathrm{Vr}$ represents the surface wave velocity. Between the specularly reflected energy (Wave 1) and the mode-converted energy (Wavc 5 or 8), inlerference con occur at slot heights given by:

$$
h_{15}=\frac{V r V s}{f\left(V_{s}-0.707 V r\right)}
$$

An experiment was performed with a series of Elox slots which simulated various lacks of penetration. Using a narrow-bandwidth pulser, transducers were excited at frequencies of $21 / 4,5,10$, and $15 \mathrm{MHz}$, and the reflected intensity as a function of slot height was determined (see Figure 4). At the test frequencies used for the data in Figure 4, the slot heights at which interference might occur were calculated from Equations 2 - 4 and are summarized in Table 1. The wave length of ultrasound in AM 363 steel and water at the test frequencies are also given. A comparison of the calculated slot heights at which interference may occur is in good agreement with the data in Figure 4. The slot heights at which 
interference occurs between Waves 1 and 5 are larger than the range of transducer sensitivity. From these data it is seen that the slot height at which interference begins to affect the measurement is inversely related to the frequency. Thus, lower-frequency techniques would be preferred in order to avoid interference problems. Unfortunately, the spot size of even a sharply focused transducer is limited to four or five wave lengths. Thus, low frequencies may be used to detect larger lacks of penetration; but, due to the larger spot
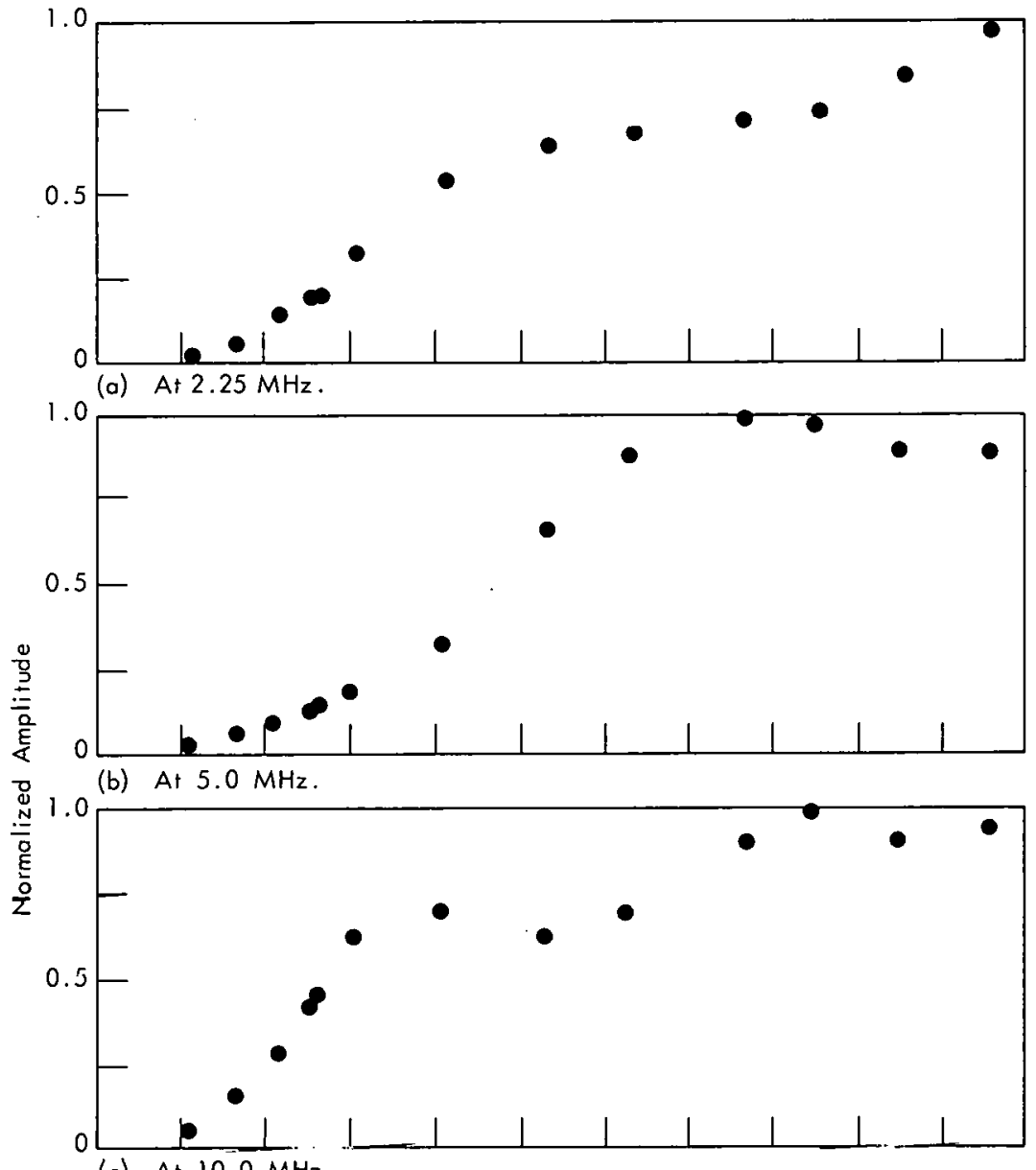

(c) At $10.0 \mathrm{MHz}$.

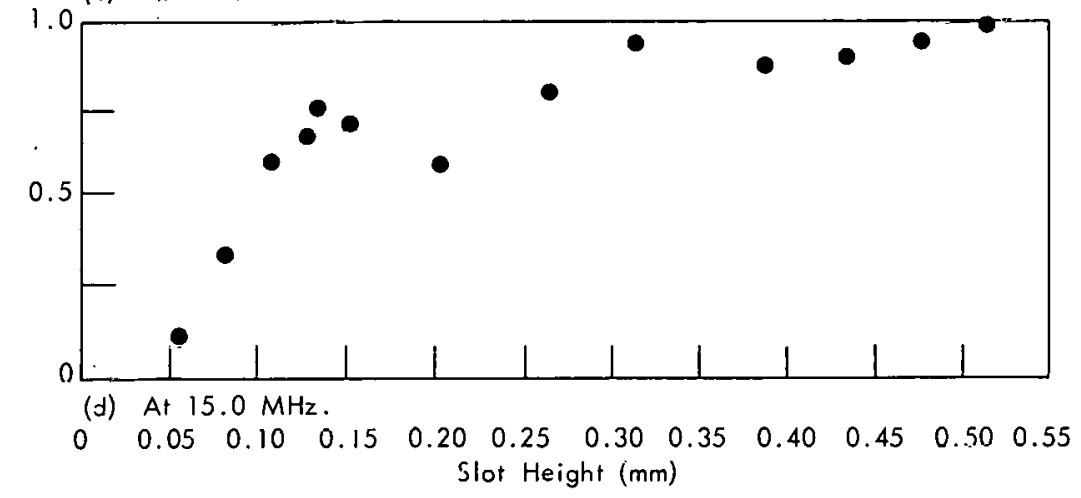

Figure 4. NORMALIZED RESPONSE FROM ELOX SLOTS AS A FUNCTION OF THE FREQUENCY. 
size, there is less sensitivity to small lacks of penetration. The best compromise for the range of slot sizes of interest is an inspection frequency of $5.0 \mathrm{MHz}$; and, thus, $5 \mathrm{MHz}$ was chosen as the toet frequens.y.

\section{STANDARDS}

In order tu calibratc instrumentalion it is necessary to produce snme repeatable signal. The busl typc of ctandarn is onte which simulates, as r.losely as possible, the flaws expected to be seen. Bince it is difficult to prnduce a weld with a known lack of penetration, a sample with Elox slots of various depths is used. This type of sample was used to calibrate the instrumentation and to characterize the different transducer configurations.

To be consistent it was decided to inspect all three welds such that sound would be incident on the corner formed by a lack of fusion at an angle of 45 degrees. This stipulation requires an incident angle of 19.1 degrees at the weld surface for the two welds, with the weld plane normal to the weld surface, and 23.5 degrees for the third weld in which the weld plane is inclined at 13 degrees to the normal of the weld surface.

A series of experiments were performed to determine if the same type of Elox standard could be used for all welds. Since two inspection angles were used, data were taken from an [lox slot sample at each angle. The data are plotted in Figure 5. Note that the responsc frum the slots was reduced by approximately $50 \%$ whieli the incident angle was increased liom 10.1 iu 23. I ir.greos.

To better define the effect of the incident angle, the response from both a 0.13 and a $0.25-\mathrm{mm}$ slot was measured as a function of the incident angle (Figure 6). Rough caleulations were made to determine the change in sound pressure transmitted through the water/steel interface. These calculations indicate that the tronsmitted snınd pressure is increased by approximalely 15\% when the incident angle is increased from 19.1 to 23.5 degrees. Thus, the decrease in response from an Elox slot with increasing angle is due to the angle in which sound is incident on the slot and not to the variation in the incident angle at the water/steel interface.

Krautkramer(2) showed that the reflection of sound from a corner is maximum at 45 degrees and decreases at angles greater or less than 45 degrees. In fact, there is a large reduction in the reflection amplitudes less than 33 degrees and greater than 57 degrees. As just indicated, an incident angle of $\mathbf{2 3 . 5}$ degrees is required to inspect the weld-root corner of the inclined weld. If an Elox slot standard is used in which the Elox slot is normal to the surface, the slot is inspected at an angle of 59.2 degrees when the incident angle is 23.5 degrees. Thus, an Elox standard design was recommended in which the rear surface and the slots are tilted to match the geometry of the inclined weld. 


\section{FUSION-PASS INSPECTION}

It is desirable to know whether the weld has sufficient penetration after the fusion pass to make repairs before the filler wire is added. In order to check the feasibility of inspecting the welds for penetration following the fusion pass, three AM 363 plates with only a fusion pass were fabricated and inspected.

After the fusion pass, the weld was from 3.8 to $5.0 \mathrm{~mm}$ wide and depressed approximately 1 $\mathrm{mm}$ from the outer surface. The weld contour acts as an ultrasonic lens which focuses the ultrasonic beam at the root of the weld. Beam-refraction calculations indicate that, when an unfocused ultrasonic beam is incident normal to the weld plate, shear energy is focused to illuminate a $1-\mathrm{mm}$-diameter spot centered at the weld root, as illustrated in Figure 7 . With proper time gating, the portion of the step parallel to the surface and within about $0.5 \mathrm{~mm}$ of the center of the weld would be detected if lack of complete fusion is present. In case of complete fusion, no signal is present in the gate. The gate length is adjusted to detect the rear surface so that the edge of the weld can be detected. Figure 8 shows the gating arrangement for this inspection.

Scans of the three plates are given in Figure 9. On Plate $A$, the weld current was reduced over a portion of the total weld length in an attempt to reduce weld penetration. Approximately $64 \mathrm{~mm}$ were completely unfused. Ultrasonic inspection detected the step over about two thirds the length of the plate, indicating a partial lack of penetration. Plates

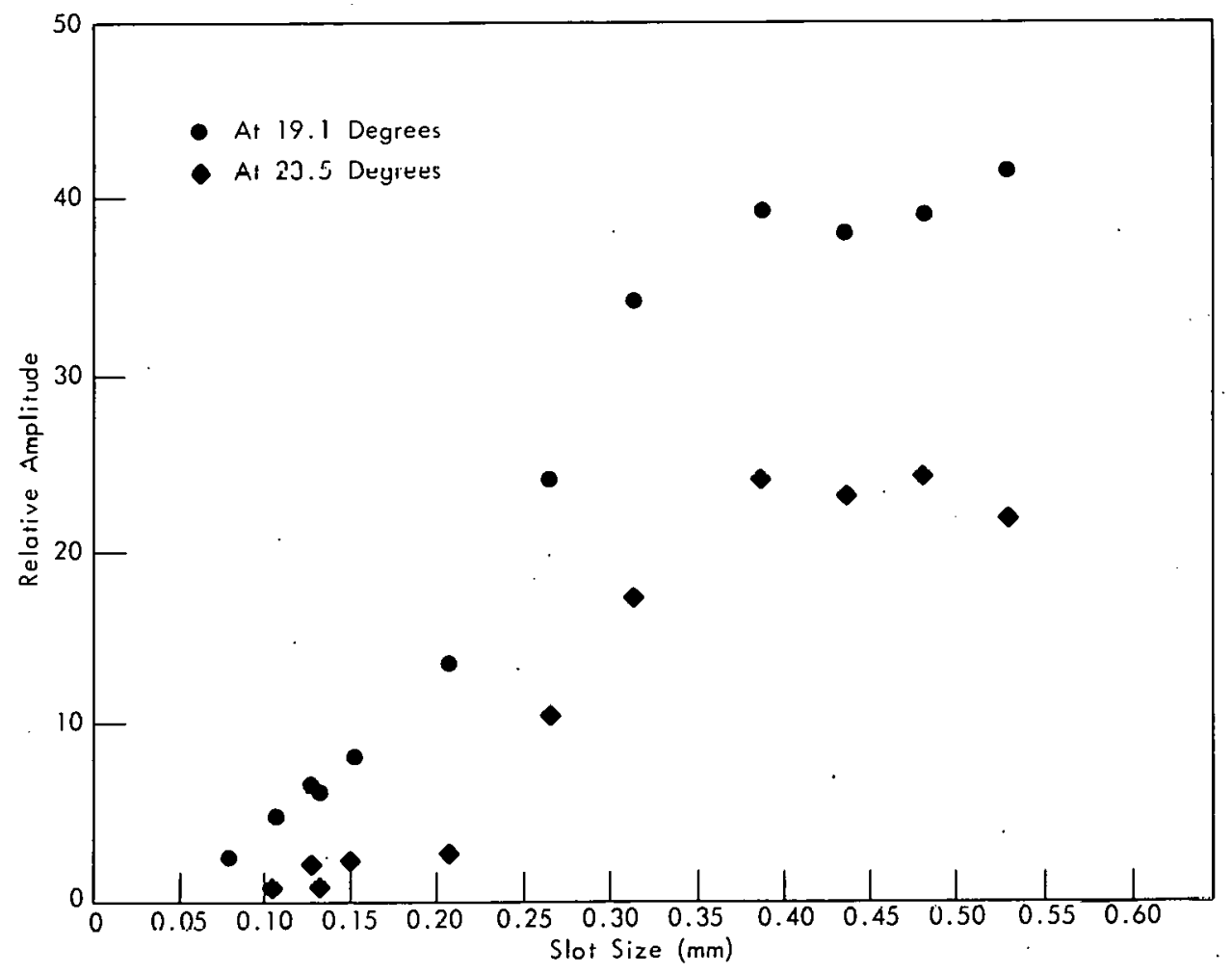

Figure 5. RESPONSE FROM AN ELOX SLOT STANDARD AT INCINENT ANGLES OF 19.1 AND 23.5 UEGREES. 
$B$ and $C$ were welded using normal welding parameters. The step was detected in about $20 \%$ of Plate $B$ and was not detected in Plate $C$.

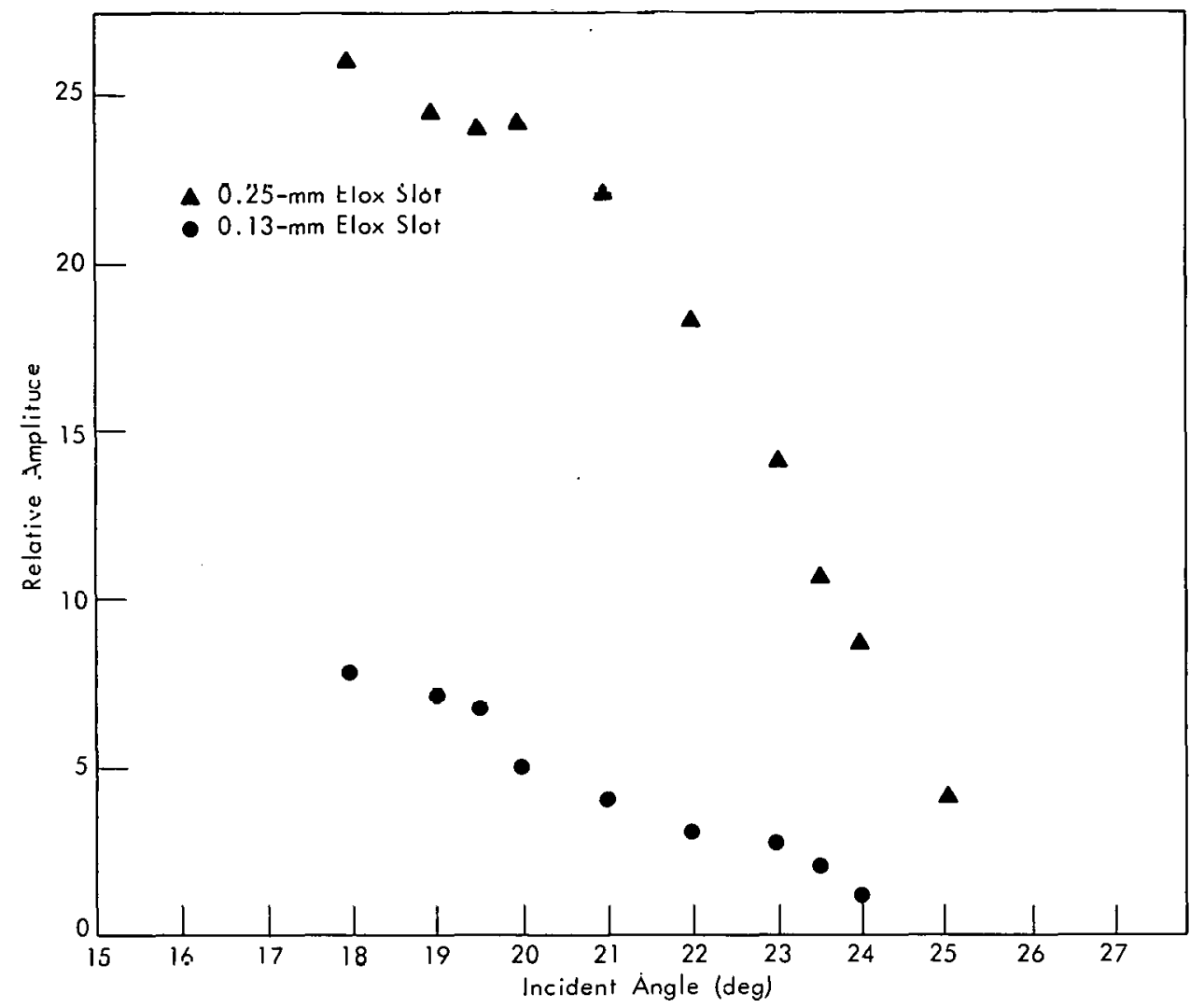

Figure 6. RESPONSE FROM 0.13 AND $0.25-\mathrm{mm}$ SLOTS AS A FUNCTION OF THE INCIDENT AnISi. F.

\section{DETECTION OF POROSITY}

Porosity was to be detected in the weld, with sizes which ranged from 0.8 to $1.3 \mathrm{~mm}$. One weld using dirty filler wire for the fusion pass was accidentally fabricated, resulting in considerable porosity. Several samples were removed from this weld for extensive study. Each sample was radiographed to image the porosity so that a correlation could be made with ultrasonic data.

The delta technique ${ }^{(3)}$ and a normal longitudinal inspection were tried, but it was found that the

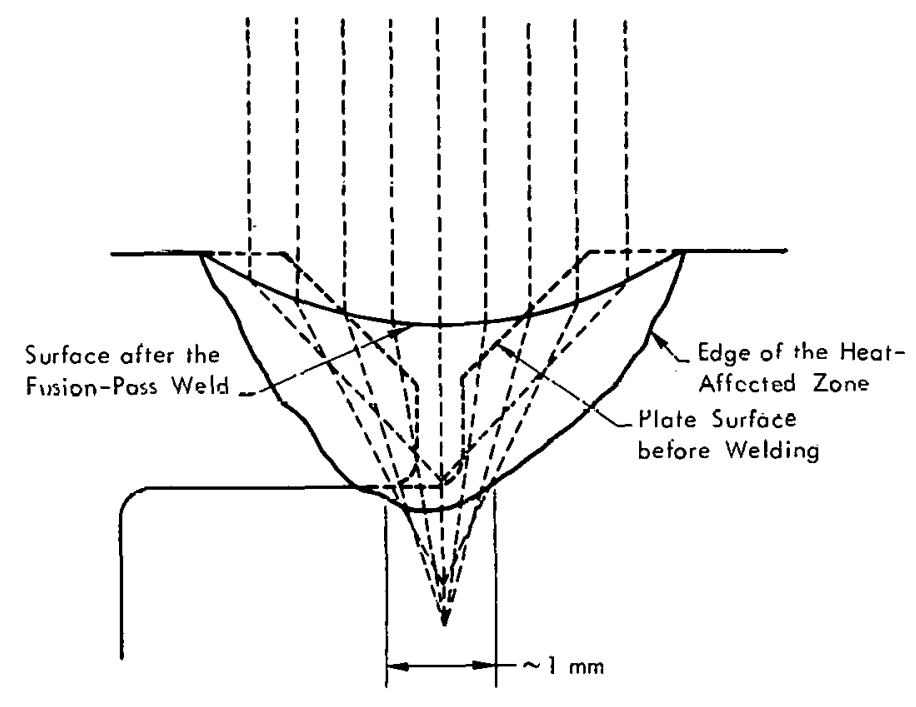

Figure 7. ULTRASONIC BEAM GEOMETRY IN A FUSION-PASS WELD. 
samples lacked the resolution required to image the porosity. Consequently, an angled-beam, shear-mode inspection was developed which was similar to the test used to certify weld penetration except that the beam is tilted tangentially along the line of the weld; that is, the transducer and weld bead lie in the same plane. This orientation eliminates reflections from the weld step and reduces the front surface signal so that indications from porosity may be detected. Since porosity may occur in any portion of the 6.4-mm-wide weld, a C-scan must be made of the weld. Figure 10 presents a diagram that illustrates the tangential shear technique used to detect porosity.

Figure 11 is a radiograph that was made of several weld samples. Each sample was cut, after the ultrasonic inspection, to a thickness of approximately $5 \mathrm{~mm}$ to improve the radiographic resolution. The varying film

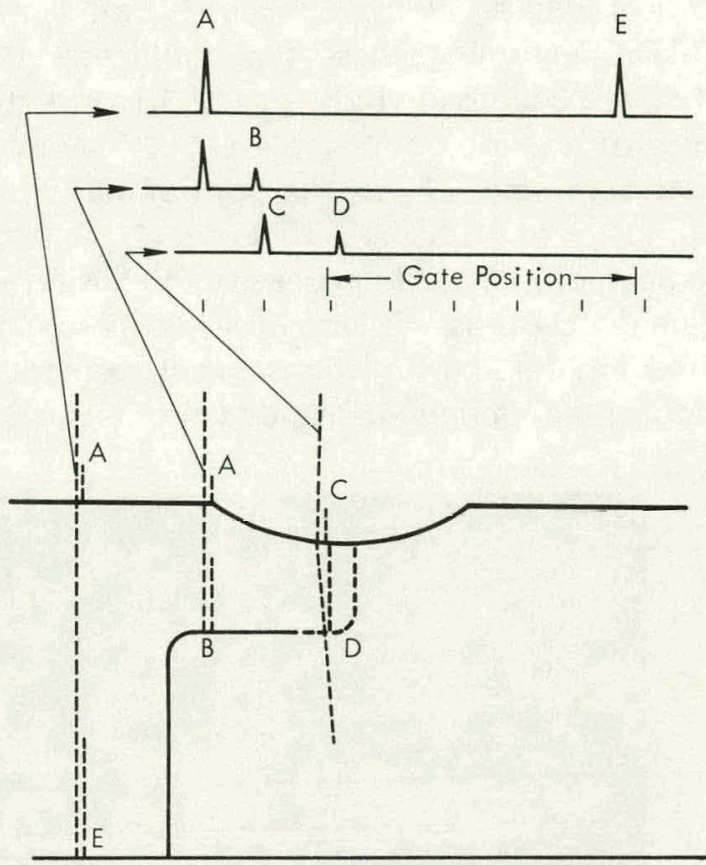

Figure 8. A-SCANS (TIME-AMPLITUDE OSCILLISCOPE TRACES) OF A FUSION-PASS WELD. density between samples is due to thickness variations. The ultrasonic results obtained from a number of these samples are given in Figure 12. The numbered flaws in Figure 11 correspond to the numbered flaws in Figure 12. In Figure 11, it should be noted that there are several flaws that look like doughnuts in the

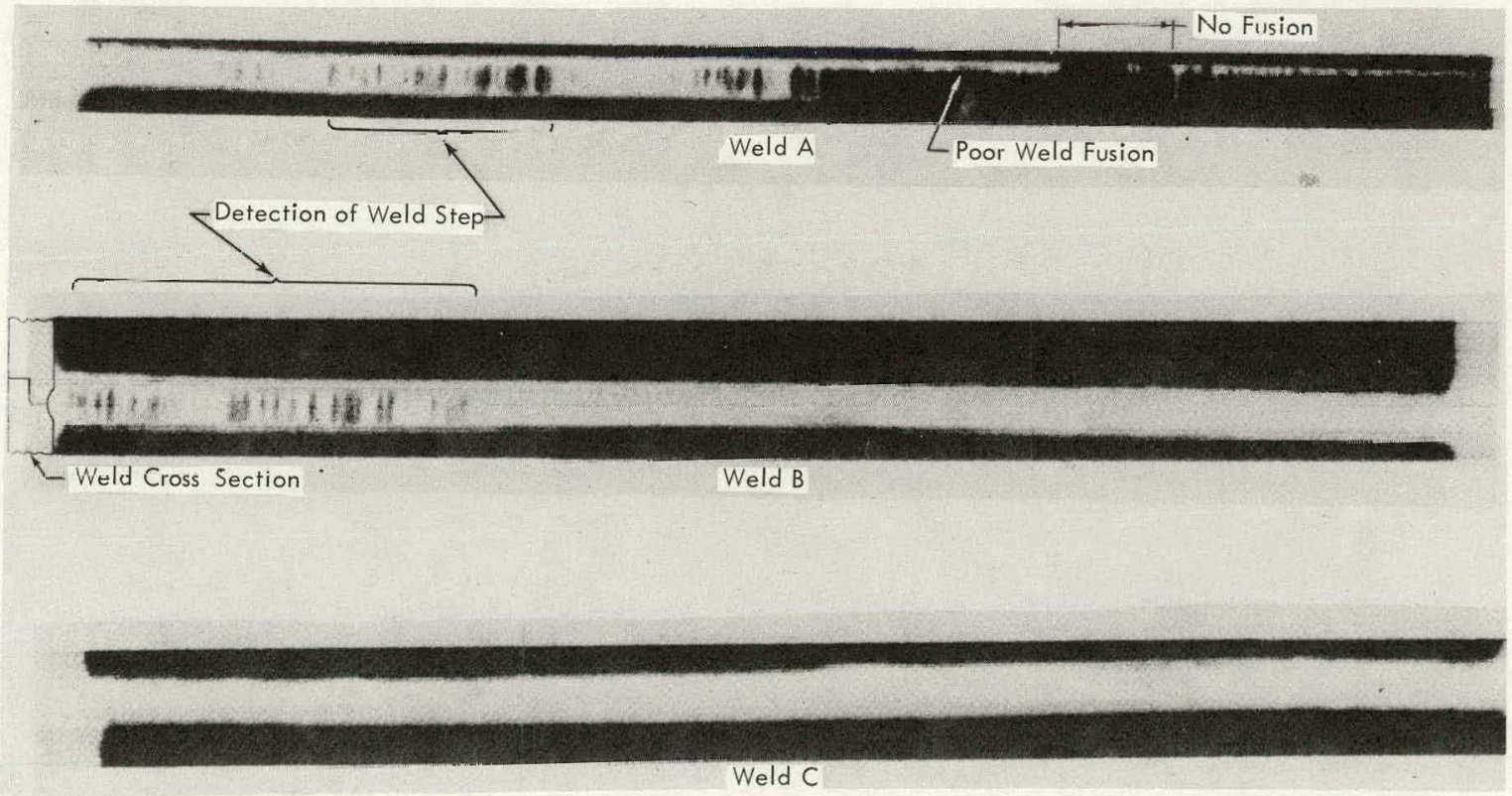

rigure 9. C-SCAN OF rUSION-PASS WELD PLATES. 
radiograph; eg, Flaws 7 and 11 in Sample $\mathrm{U}-5 \mathrm{~B}$. Sectioning these flaws indicates that they are collapsed voids. Figure 13 presents a view of a section of Sample U-5B. In View a, Flaws 11 and 12 can be seen along with a number of smaller flaws seen in the radiograph. The high-density inclusion in Sample U-6B is a piece of the tungsten tip used for welding. View $b$ is an enlargement of a collapsed, doughnut-shaped void.
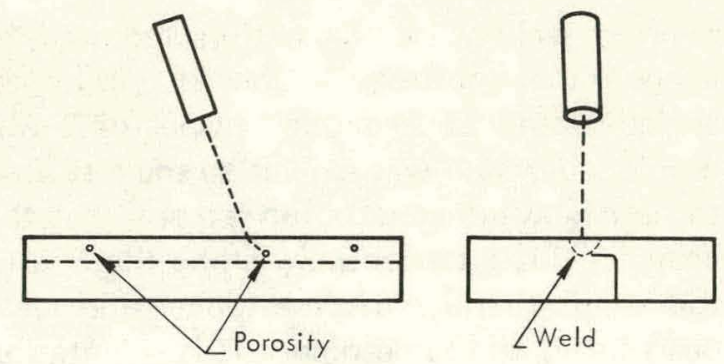

Figure 10. TANGENTIAL SHEAR TEST FOR POROSITY.

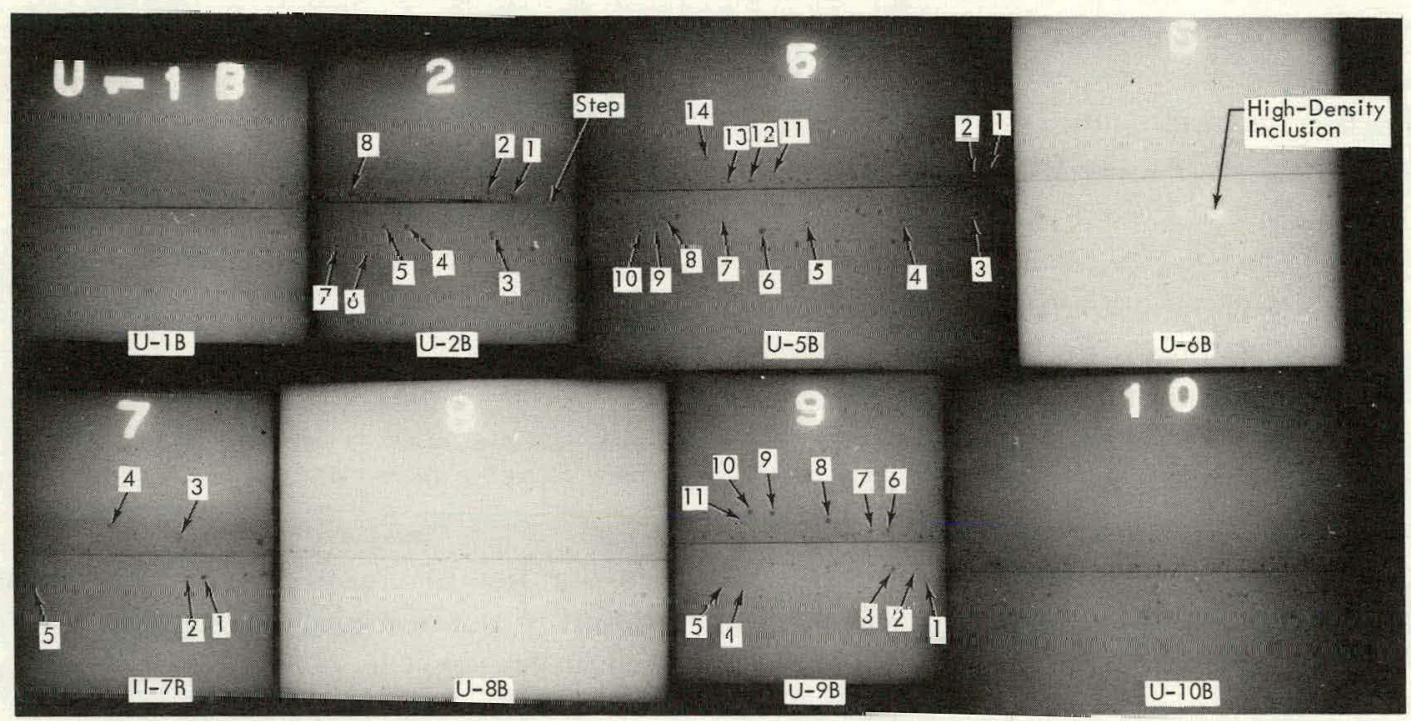

Figure 11. RADIOGRAPHS OF TYPICAL POROSITY SAMPLES.
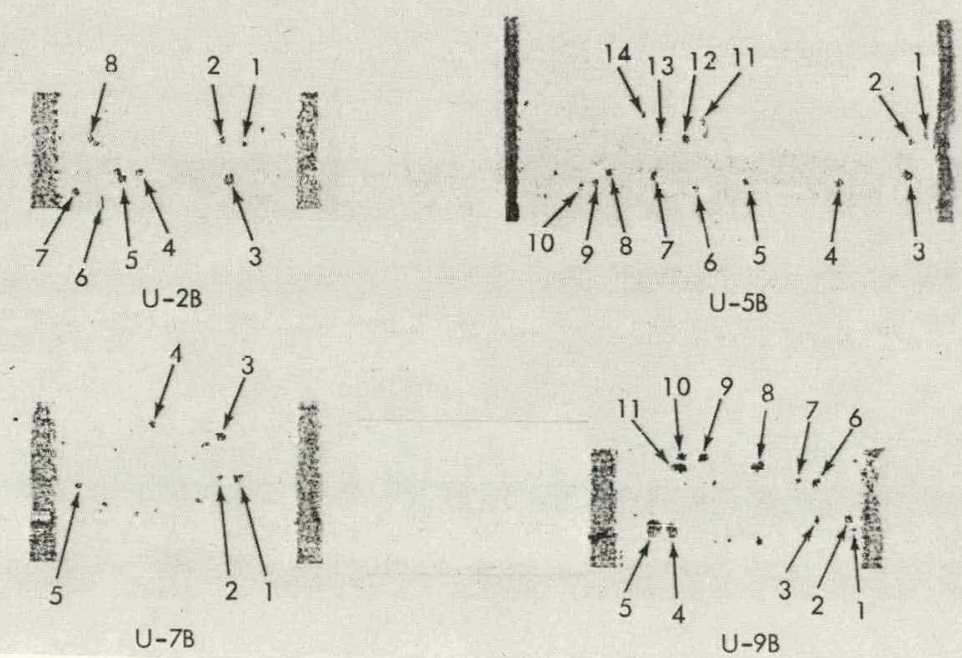
A plot of flaw size versus ultrasonic response is presented in Figure 14. The flaw size was measured by a $5 \mathrm{X}$ eyepiece from the radiographs, and the ultrasonic response was determined to within 2 db. Sicallar in the data can be attributed to flaw orienılaliun, imprecise ultrasonic measurements, inaccuracies in measurement of flaw size on the radiographs, and to thin portions of the flaw not detected by radiography but by ultrasonics. For example, Figure 15 is a photomicrograph of Flaw 2 on Sample U-7B. The stringer below the void contributes to the intensity of lle reflected ultrasonic signal, but does not affect the radiation attentuation in the material so that radiography indicates a smaller flaw than does ultrasonics. While the scatter is large and a stricl currelation is not obtained, these data are significant because they represent the ability to detect, with confidence, voids as small as $0.5 \mathrm{~mm}$, even when they are very near the surface.

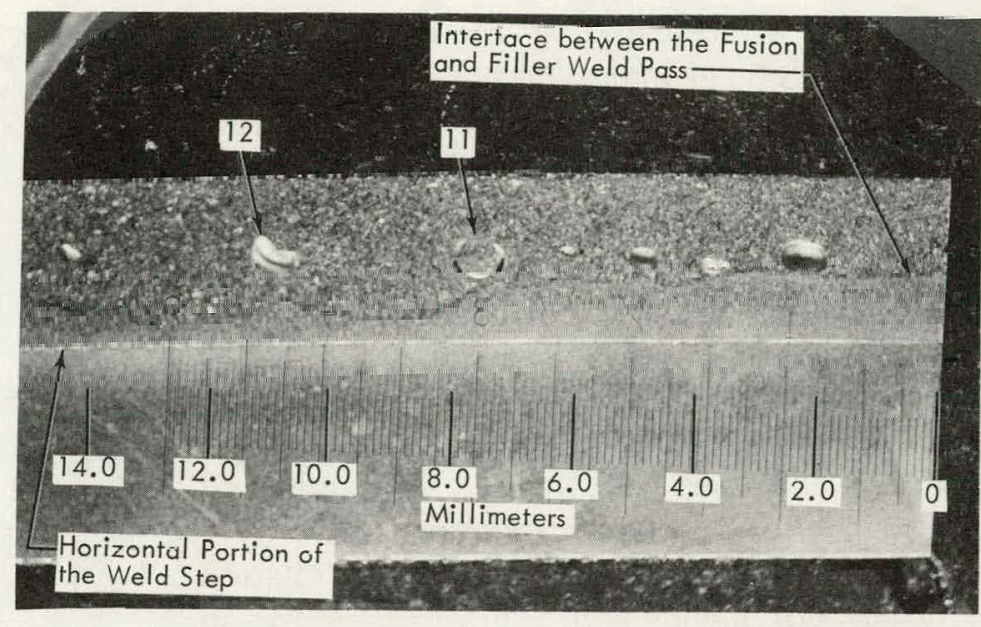

(a) Flaws 11 and 12. (8X)

MS-72-0267-32

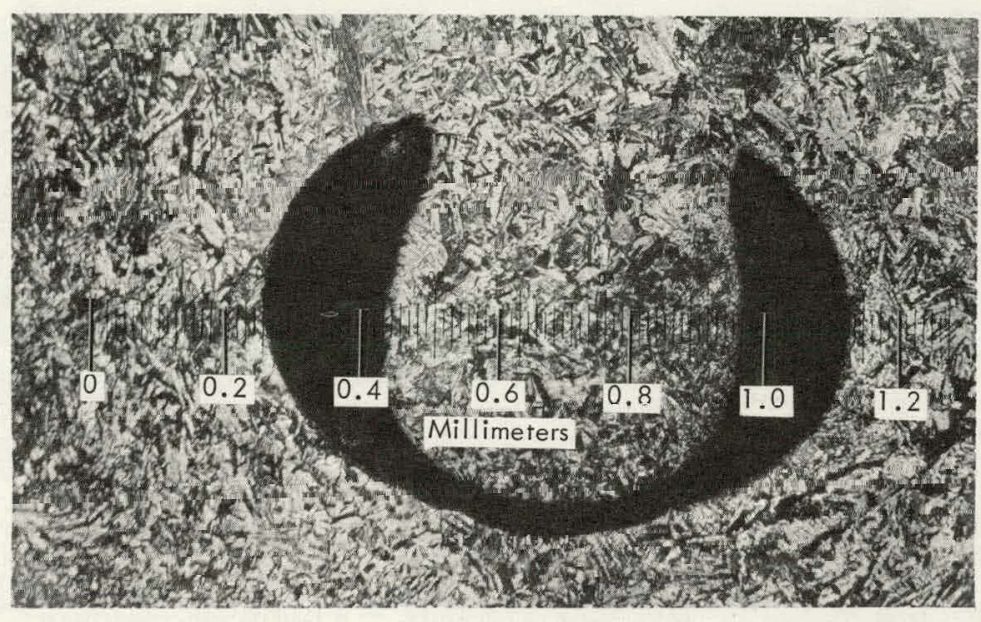

(b) Flaw 11. (100X)

MS-72-0267-31

Figure 13. SECTION OF WELD SAMPLE U-5B, SHOWING COLLAPSED VOID AND OTHER POROSITY.

It should be noted that the flaws detected are not typical of a majority of the welds. It is suspected that this weld was made with dirty filler wire. The majority of flaws appeared to be located near the bottom of the filler pass, as seen in View a of Figure 13.

Porosity in welds has random orientation so that it is difficult to obtain a correlation between porosity size and a calibration signal, such as the signals from a series of Elox slots. But, since, in these welds, the most difficult condition would be spherical porosity, porosity was simulated by a series of holes of different diameters machined with spherical bottoms. Figure 16 points out the details of the simulated-porosity sample. It was desirable to use Elox slots as standards since they are easier to fabricate than spherical-bottom holes, and easier to inspect. However, a correlation between Elox slot size and the hole size is required. Since weld penetration is inspected by a similar transducer orientation to the porosity inspection, the same inspection angle is used for the porosity inspection. Since two inspection angles are required for the weld penetration inspection, spherical-bottom-hole 
samples were fabricated for inspection at both 19.1 and 23.5 degrees. The hole diameter was measured by replicating each hole and measuring the replicas optically.

In order to determine the correlation between Elox slot height and spherical hole diameter, the response from both the holes and the slots was measured. An equation was derived to describe the relation between slot height and response and used to calculate the equivalent slot height for a given response measured frum eac.h hole. Fiqure 17 illustrates the relation between slot height and hole diameter for an inspection angle of 19.1 degrees; Figure 18 shows the same data for an inspection anyle of 23.5 degrees. In order to inspect the calibration slots at 45 degrees, a "dimpled" standard was fabricated. A typical Elox slot in the dimpled standard is indicated in Figure 19. Correlation between the regular standards (Elox slots normal to the surface) and the dimpled standards is noted in Figure 20 for an incident angle of 23.5 degrees. The increased sensitivity obtained by looking at an Elox slot at 45 degrees can be easily seen.

\section{PRODUCTION TESTING}

The components being welded are too large to be immersed in a tank of water for inspection. Thus, in order to couple the transducer to the weld for inspecliun it is necessary to use a water jacket known as a "bubbler". Fiyure 21 shows a bubblor set up for

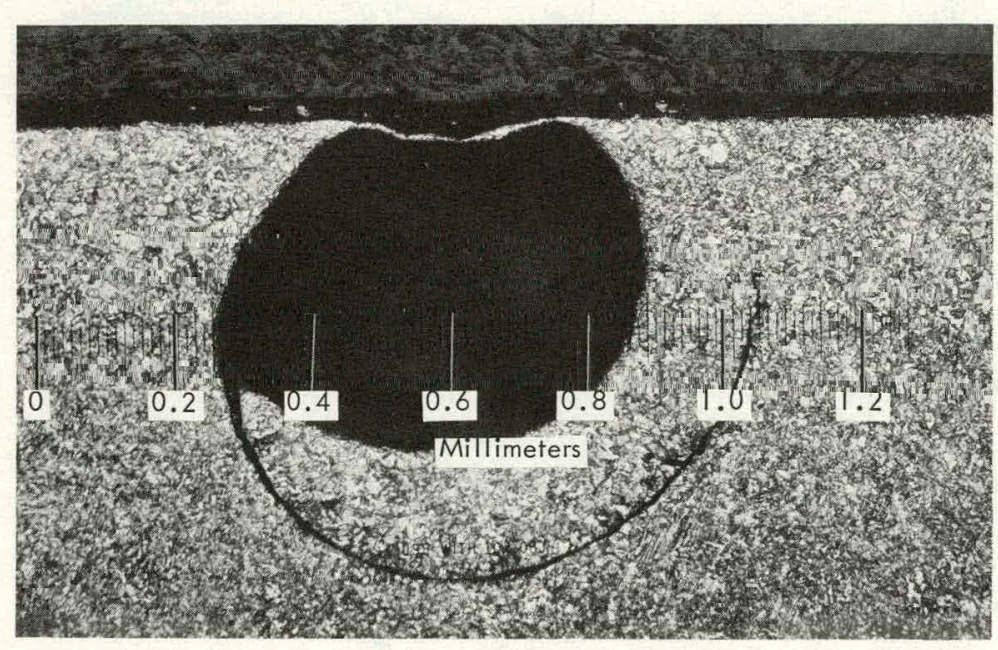

MS-72-0277-8
Figure 15. FLAW 2 IN SAMPLE U-7B. (100X) inspection. A small water flow is required to maintain coupling and prevent air bubbles from interfering with the water path. The bubbler system allows all inspections to be made without having to immerse the components in water.

The fusion pass inspection was made first. This inspection intended to serve as a courtesy check to the welding engineer and was performed with the components mounted in the welding fixture. A flat-ended 

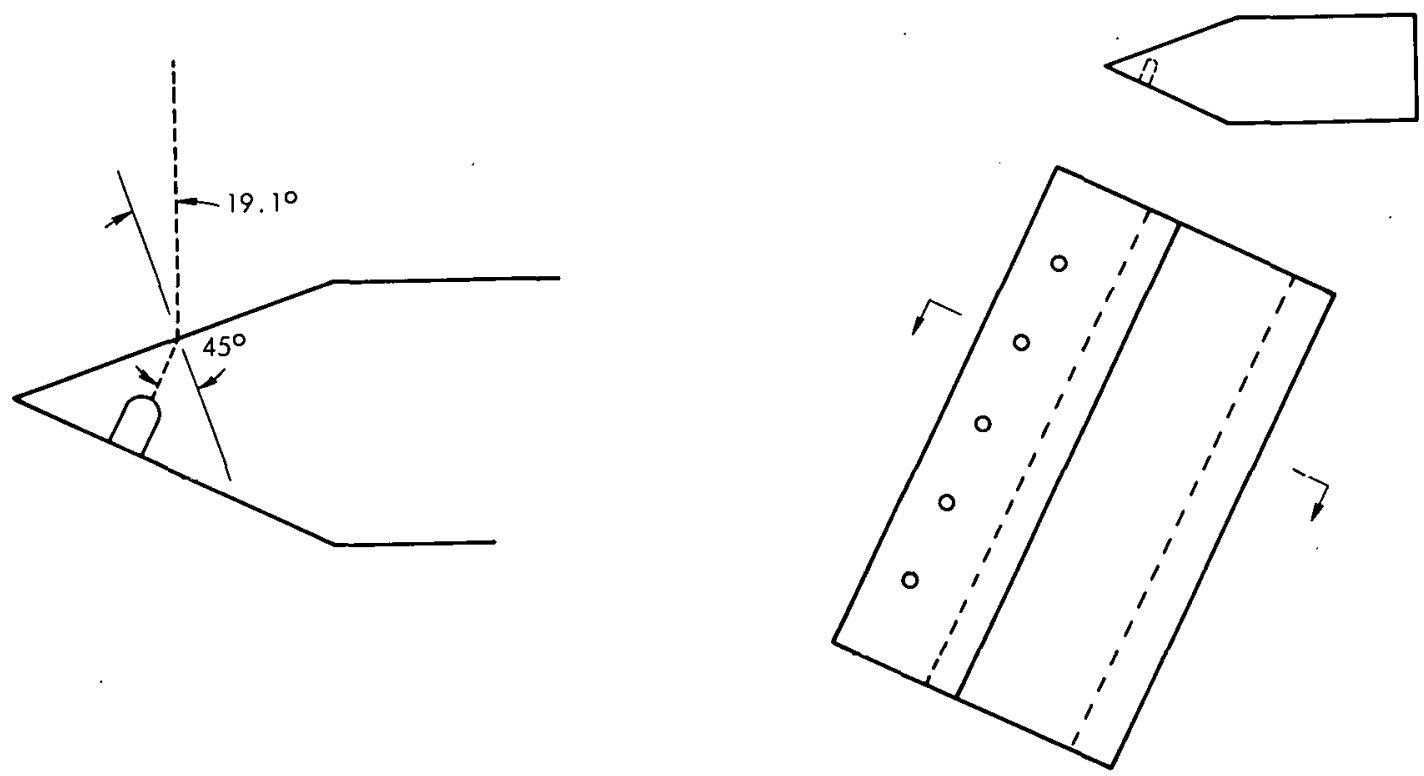

Figure 16. ROUND-BOTTOM-HOLE POROSITY SAMPLE.

bubbler was used. On actual inspections, the fusion-pass inspection technique was difficult to use because of variations in the weld-surface contour from one weld to the next. In addition, techniques were developed to repair, with reasonable ease, the weld after the filler pass. Thus, the fusion-pass inspection was dropped.

In place of the fusion-pass inspection, a shear-wave angled-beam inspection is performed to detect lack of fusion after the filler weld is made, but before the part is removed from the welding fixture. If any flaws are detected, the weld can easily be repaired. Assuming no flaws are detected, the welded section is sent to the nondestructive testing area for certification. The shear-wave angled-beam inspection is repeated to detect lack of penetration. The front end of the bubbler is cut at the proper angle for the particular weld (19.1 or 23.5 degrees), and a strip-chart recording of the signal response from the weld root is obtained. The amplitude of the signal response is compared with the response from the appropriate standard.

If the weld is fully penetrated with no flaws at the weld root, it is difficult to position the transducer so that its energy is centered at the weld root without some reference location. The shoulder (see Figure 1) of the step welds is used as a reference location by peaking the signal from the shoulder and then translating the transducer the appropriate distance to center it on the weld root. Although the plate weld (Figure 1, View b) has no shoulder to use as a reference location, it is located close enough to the normal step weld (Figure 1 , View a) so that the step-weld shoulder can be used as a reference.

Figure 22 is a photomicrograph of lack of penetration detected in a production weld. Comparison of the ultrasonic signal from the flaw with a standard, indicated a flaw size of about $0.20 \mathrm{~mm}$, which is close to the size indicated on the photomicrograph. Standard flaw-detection electronics are used, including a pulser/receiver operated at $5 \mathrm{MHz}$ and an analog flaw gate capable of gating the șignal received from the weld root and producing an analog signal proportional to the gated-signal amplitude. A 5- $\mathrm{MHz}$ highly damped transducer is used. 

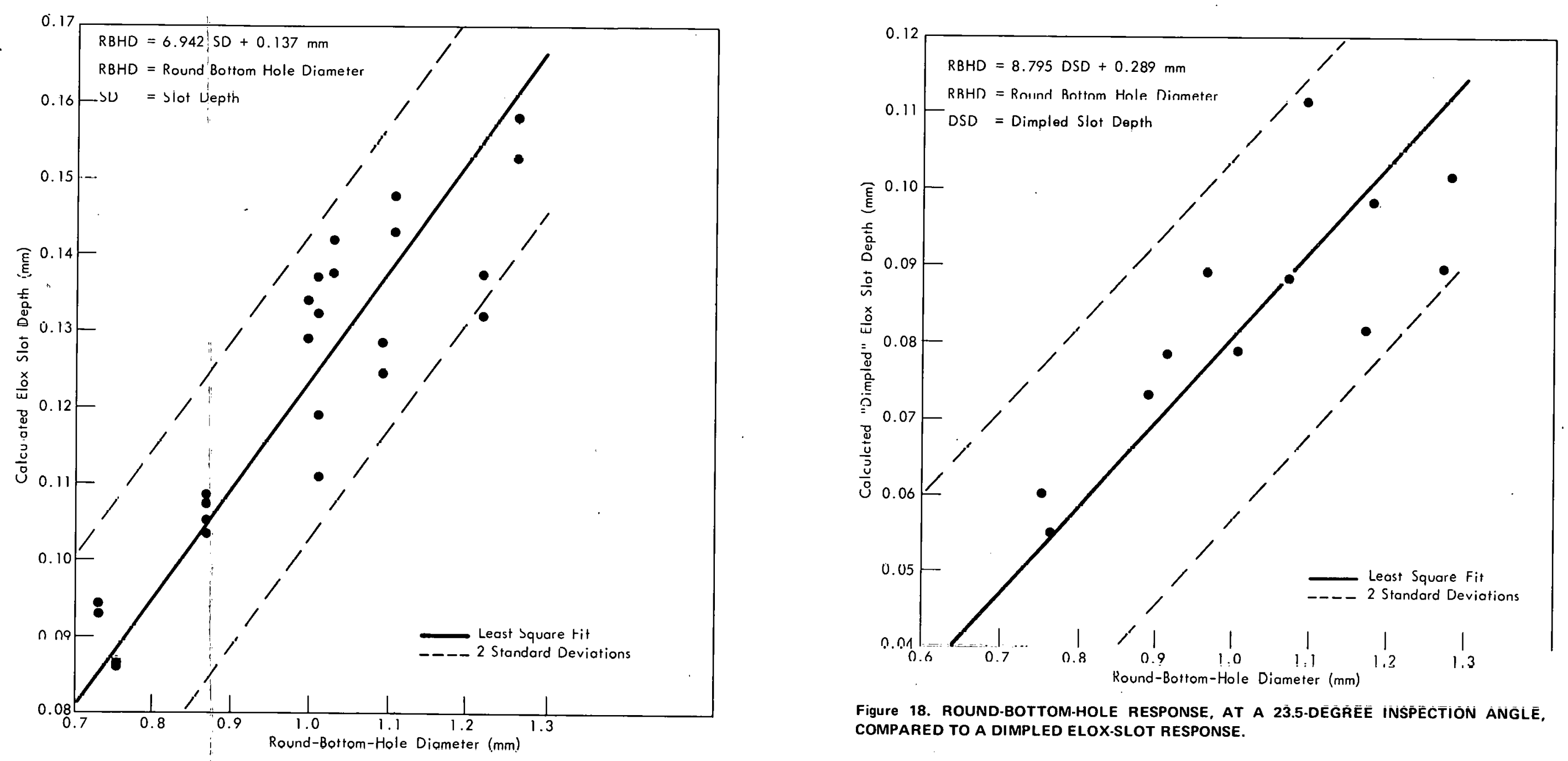

Figure 18. ROUND-BOTTOM-HOLE RESPONSE, AT A 23.5.DEGGEEE INSPEECTION ANGGLÉ, COMPARED TO A DIMPLED ELOX-SLOT RESPONSE.

Figure 17. ROUND-BOTTOM-HULE HESPUNSE, AT A 19.1-UEGHEE INSPECTION ANGLE, COMPARED TO AN ELOX-SLOT RESPONSE. 
For the porosity inspection, the transducer head is rotated 90 degrees (as in Figure 10) and the transducer is scanned in a raster pattern to cover the width of the weld. A threshold is adjusted, using the standard, and a C-scan recording is made similar to the scans shown in Figure 12. The amplitudes of any indications are compared with the standards to obtain an estimate of the flaw size.

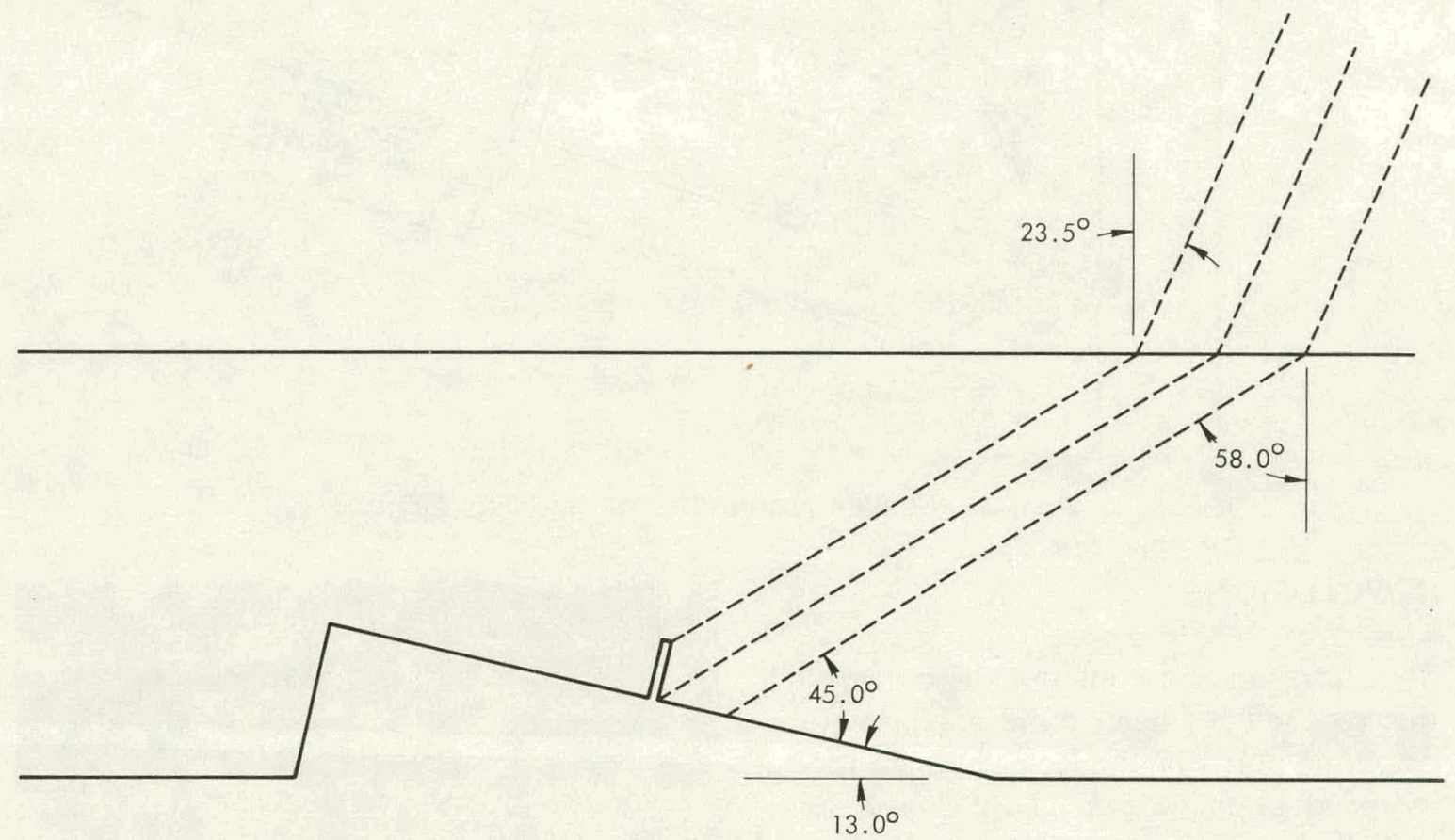

Figure 19. DIMPLED ELOX-SLOT RESPONSE.

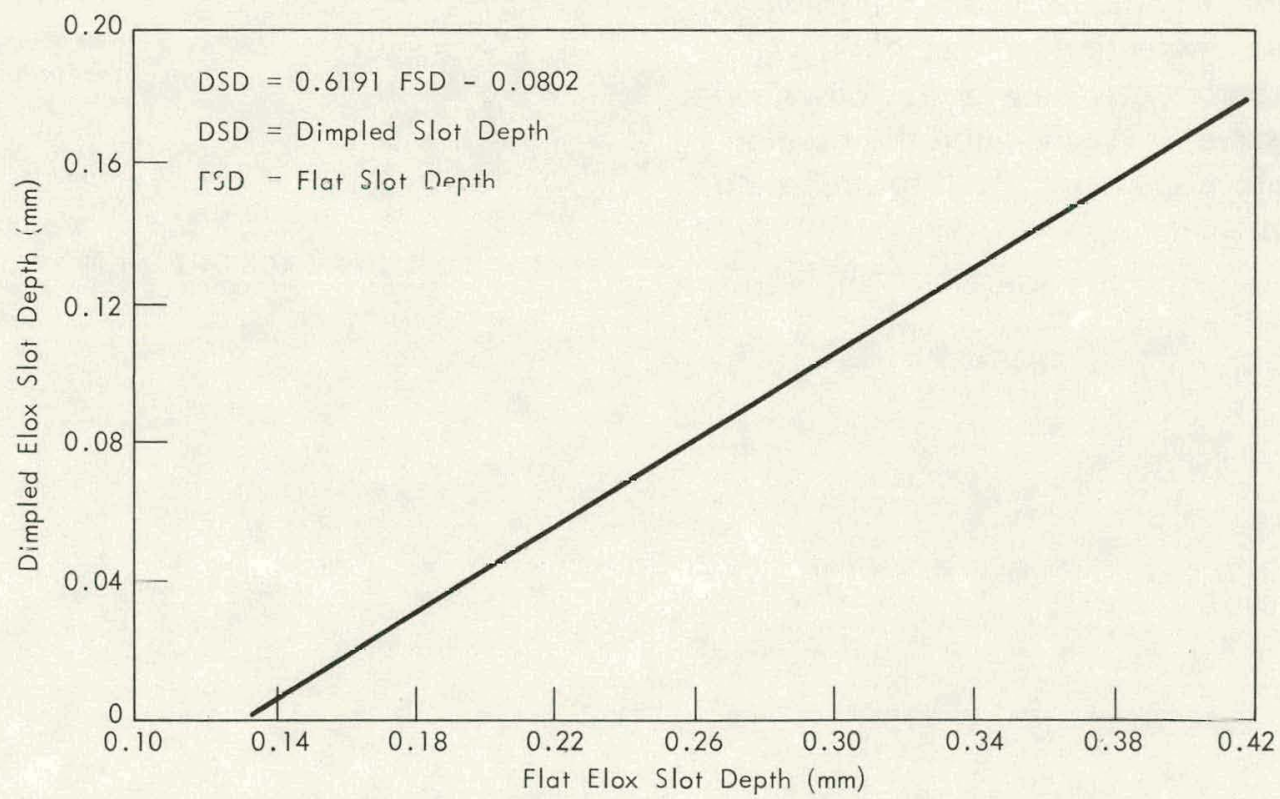

Figure 20. DIMPLED ELOX SLOTS COMPARED TO FLAT ELOX SLÜTS AT AN INSPECTION ANGLE OF 23.5 DEGREES. 


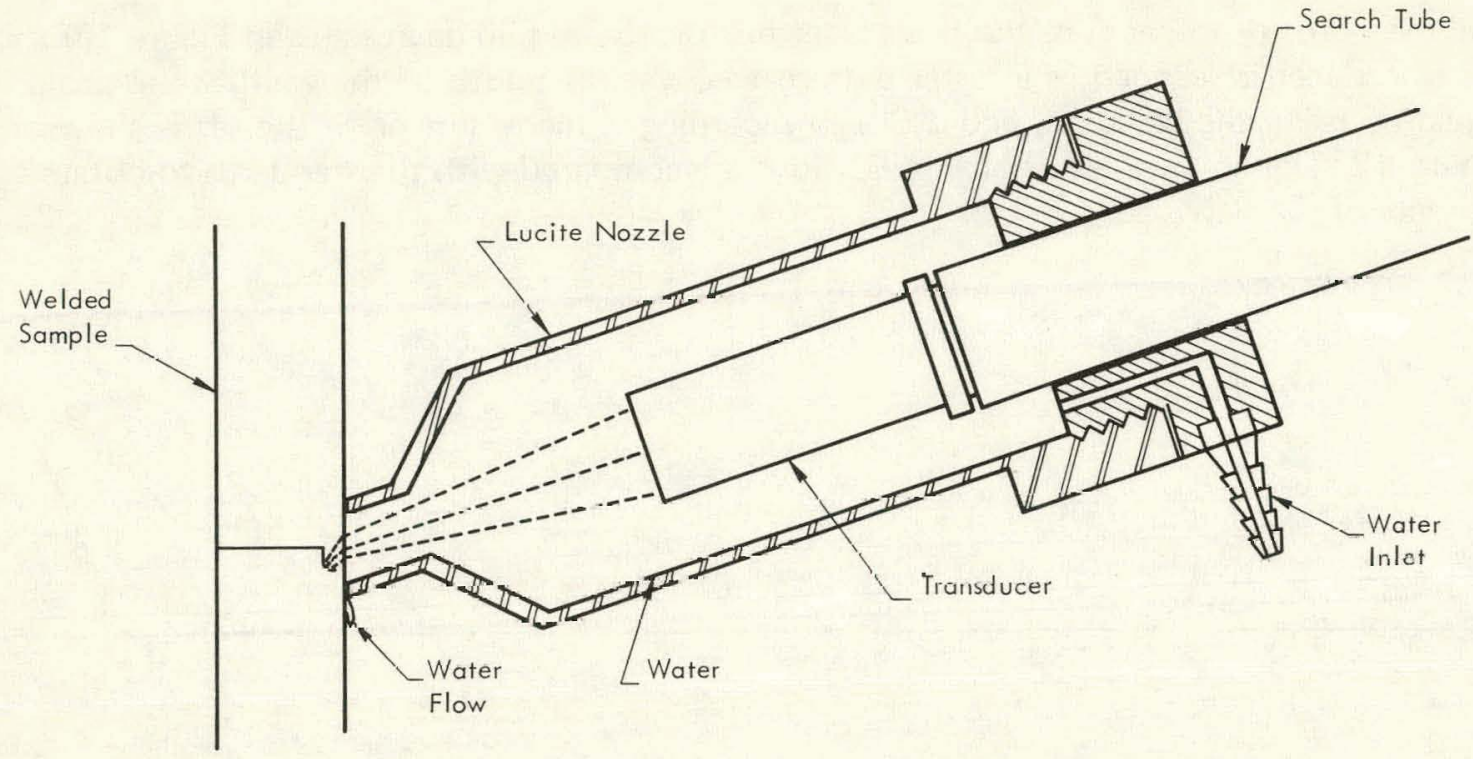

Figure 21. BUBBLER TECHNIOUF FOR WELD INSPECTION.

\section{CONCLUSIONS}

The ultrasonic techniques described in this report have been quite adequate for detecting porosity and lack of penetration in production welds. This study has indicated that consideration must be given to weld geometry, flaw geometry, transducer frequency and orientation, and calibration techniques when designıng an ultrasunic inspection to certify a weld. The experiments and tests described should serve as a guide for the development of inspections for future weld problems.

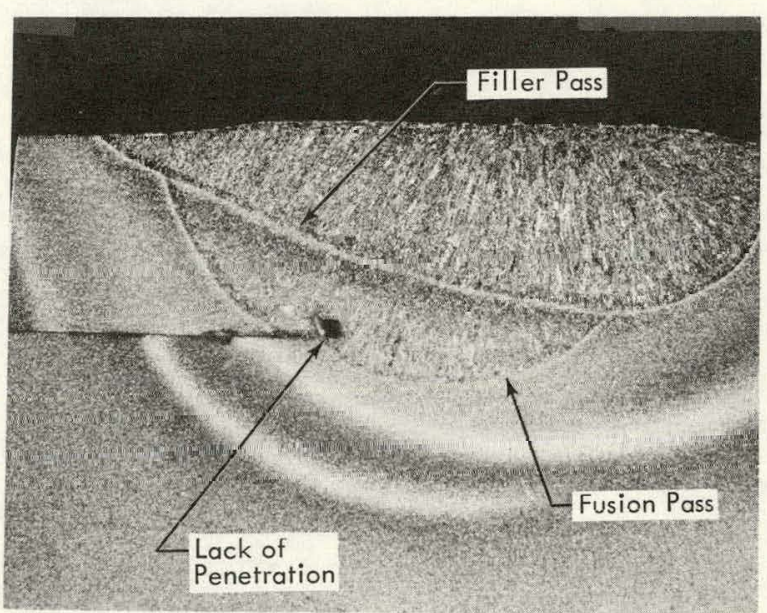

MS-73-0623-20

Figure 22. WELD WITH A LACK OF PENETRATION. (10X) 


\section{REFERENCES}

(1) Frielinghaus, R., Krautkramer, J., and Schlengermann, V.; "Problems Associated with Ultrasonic Reference Defects", Nondestructive Testing, 3, (2), pp 125-127; April 1970.

(2) Krautkramer, J. and Krautkramer, H.; Ultrasonic Testing of Materials, p $37 \mathrm{ff}$; Springer-Verlag, New York, Inc (1969).

(3) Cross, B. T., Hannah, K. J., and Tooley, W. M.; The Delta Technique-A Research Tool-A Quality Assurance Tool, TR 68-11; Automation Industries, Inc (1968). 


\section{ACKNOWLEDGEMENTS}

The experiments involved in this program have spanned a period of at least three years. The author acknowledges the assistance of J. D. Elkins, who was responsible for transferring the inspection from development to production; G. W. Scott, who provided standards and many of the samples and coupons for the porosity experiments and also coordinated the sectioning and photography of the porosity samples; and D. W. Koerner, who ran several of the round-bottom-hole correlation experiments with production equipment. 
Distribution

Dow - Rocky Flats

Lott, L. A.

Seed, J. R.

Skulski, R.

Energy Research and Development

Administration - Oak Ridge

Hickman, H. D.

Leed, R. E.

Zachry, D. S., Jr

Holifield National Laboratory

Berry, L. A.

Brinkman, C. R.

Canonico, D. A.

Cook, K. V.

Greenstreet, B. L.

McClung, R. W.

Lawrence Livermore Laboratory

MacMillan, K.

Stuart, F. R.

Sully, J. W.

Weiss, H. P.

Woeffler, W. A.

Oak Ridge Gaseous Diffusion Plant

Blake, W. H.

Wilcox, W. J., Jr

Winkel, R. A.

Oak Ridge Y-12 Plant

Alvey, H. E.

Austin, L. A.

Burditt, R. B.

Burkhart, L. E.

Butturini, W. G.

Elkins, J. D.

Foulk, D. L.

Fraser, R. J.

Gritzner, V. B.

Hensley, C. E.

Jackson, V. C.

Jones, F. W. 
Kahl, K. G.

Sandia - Livermore

Keith, A.

Kite, H. T.

Dini, J. W.

Knowles, C. $M$.

Mote, M. W.

Koerner, D. W.

Scholar, G. R.

Long, P. J.

Swisher, J. M.

Lurndin, M. I.

Willis, A. R.

Mason, D. L.

Zinkc, W. D:

Moyer, M. W. (5)

Mills, J. M., Jr

Oliphant, G. W.

Ulmsteàd, C. D.

Pcrry, $\wedge, E$.

Pliillips, L. A.

Schneider, P. G.

Schreyer, J. M.

Scott, G. W.

Smith, H. F., Jr

Smith, R. D.

Stoner, H. H.

Tewes, W. E.

Tilson, F. V.

Weathersby, W. E.

Whitehead, H. E.

Whitson, W. K.

Yaggi, W. J./Googin, J. M.

Y-12 Central Files (5)

$Y-12$ Central Files (master copy)

Y-12 Central Files (route copy)

$Y-12$ Central Files $(Y-12 R C)$

Zerby, C. D.

Paducah Gaseous Diffusion Plant

Millican, $R$.

\section{Sandia - Albuquerque}

Mauney, C. H.

Neilson, F. W.

Schwoebel, R. L.

In addition, this report is distributed in accordance with the category UC-38, Engineering and Equipment, as given in the USERDA Standard Distribution Lists for Unclassified Scientific and Technical Reports, TID-4500. 